\title{
Bromate Content in Thirty Different Brands of Bread Baked in Port Harcourt Metropolis Rivers State, Nigeria
}

\author{
*11NAZE, AU; ${ }^{1}$ EPETE, OA; ${ }^{2}$ OWHOEKE, E \\ ${ }^{I}$ Department of Chemistry, Faculty of Natural and Applied Sciences, Ignatius Ajuru University of Education, Rumuolumeni, Port \\ Harcourt, Nigeria \\ ${ }^{2}$ Department of Pure and Industrial Chemistry, Postgraduate Unit, Faculty of Sciences, University of Port Harcourt, Port Harcourt, \\ Nigeria \\ Corresponding author Email: ugo.naze@yahoo.com
}

\begin{abstract}
This work considered the presence of potassium bromate in thirty different bread brands baked in Port Harcourt metropolis of Rivers State, Nigeria. The analysis was carried out in two locations of South and North, Port Harcourt metropolis with fifteen samples for each. The study revealed the presence of potassium bromate in all the samples $0.025-0.058 \mathrm{mg} / \mathrm{Kg}$ and 0.011 $0.059 \mathrm{mg} / \mathrm{Kg}$ for south and north respectively. It also revealed the mean to be $0.048 \pm 0.010 \mathrm{mg} / \mathrm{Kg}$ for south and $0.041 \pm 0.008 \mathrm{mg} / \mathrm{Kg}$ for the north, Apart from one of the samples (B10analyzed, the concentrations ranged from), all the values were above the allowed limit by NAFDAC. The result showed that both locations have bakeries that use bromate content higher than permissible limit. It is therefore advisable that consumption of bread from the study area may be of harmful effect due to bioaccumulation over a period of time.
\end{abstract}

\section{DOI: https://dx.doi.org/10.4314/jasem.v22i8.29}

Copyright: Copyright $(0) 2018$ Naze et al. This is an open access article distributed under the Creative Commons Attribution License (CCL), which permits unrestricted use, distribution, and reproduction in any medium, provided the original work is properly cited.

Dates: Received: 25 June 2018; Revised: 28 July: 2018; Accepted: 15 August 2018

Keywords: Potassium Bromate, Analysis, Bread and Spectrophotometer

Bread as the oldest staple food, is of great historical importance to many societies and nations around the world (Abu-Obaid et al. 2016). This could be traced back to the ancient Israel where they also used bread while in the land of Egypt. It is a common food for all classes of people because of its nutritive value and availability. Historically, it has been proven that bread as a commodity, had served as a currency in some societies as it was used for purchase of basic necessities money could buy (Maziya-Dixon et al. 2004). In Nigeria bread is an essential food item because it is readily available and at a very low price. This makes it possible for all income earners to afford it. It is extensively consumed in homes, restaurants and hotels (Emeji et al., 2009). It is mainly produced from wheat, with addition of other components like yeast, sugar, baking powder, potassium bromate etc. Shuaibu and Ibrahim (2012) examined breads around Katsina, their findings indicated that bakers within the study area exceeded the set limit. Abdull and Hassan, (2009) analyzed 15 bread samples from Hawler city of Iraq by spectrophotometric method and found potassium bromate in all the bread samples in the range of $11.09-67.45 \mathrm{ppm}$.

Potassium Bromate acts as oxidizing agents, by helping to improve the dough by giving it long elasticity, rises the bread and better quality of the final product. Potassium bromate though a bread quality improver but at high amount, is highly carcinogenic, causes low libido and renal damage. In some countries like India, Sri Lanka, Germany and Ugandan the use of potassium bromate as bread improver is highly prohibited and an offence. The world health organization and National Agency for Food and Drug Administration Control (NAFDAC) has stipulated the amount of bromate that should be used as bread improver, which they put at $0.02 \mathrm{mg} / \mathrm{Kg}$ of bread produced (FAO/WHO, 1992; Akunyili, 2005). Though this limit has been set, bread producers sometimes still go beyond the set standard. This study is imperative to check the compliance of bread producers to the standard set by national and international agencies.

Therefore, this study was undertaken to determine the levels of bromate in selected bread samples consumed in Port Harcourt metropolis using UV/Vis Spectrophotometric method of analysis. This will help to check the possibility of exposure to bromate by consumers of such breads from the areas. This research work will help to also ascertain the level of compliance with the National limit of bromate in bread. 


\section{MATERIALS AND METHOD}

Collection of Sample: Bread samples were collected from different bakeries within selected bakeries in Port Harcourt metropolis and analyzed using Ultra Violet Visible Spectrophotometric Method. A total of thirty (30) different brands of bread were used in this study, 15 samples each from both Port Harcourt South and North study locations.

Preparation of Sample: The method of (Alli et al., 2013) was used for this experiment. $10 \mathrm{~g}$ sample of the analyte was taken from the centre of the loaf of bread. This was dried in an oven for an hour at temperature of $75^{\circ} \mathrm{C}$. The dried sample was pulverized and $1 \mathrm{~g}$ of the sample was weighed into a clean $250 \mathrm{~cm}^{3}$ beaker, to this was added $20 \mathrm{~cm}^{3}$ of deionized water. The mixture was stirred thoroughly and filtered using a Whatman no 1 filter paper. $8 \mathrm{~cm}^{3}$ of the filtrate solution was transferred into a $20 \mathrm{~cm}^{3}$ volumetric tube and mixed with $1 \mathrm{~cm}^{3}$ of $0.01 \mathrm{M}$ promethazine. $0.2 \mathrm{~cm}^{3}$ of $12 \mathrm{M}$ hydrochloric acid was added; the mixture was shaken for 1 minute and used for analysis.

Preparation of Standard Solutions: 50mg of potassium bromate was dissolved in distilled deionized water and diluted to 1 litre. $3.21 \mathrm{~g}$ of promethazine hydrochloride (PTZ) was dissolved in distilled deionized water and diluted to 1 litre to obtain stock solution of $0.01 \mathrm{M}$ of PTZ. Also, $2.84 \mathrm{~g}$ of promethazine was similarly dissolved in 1 litre of distilled deionized water to obtain stock solution of $0.01 \mathrm{M}$ promethazine.

Sample analysis: Qualitative tests were performed directly on a portion of each bread sample with $2 \mathrm{~cm}^{3}$ of $0.01 \mathrm{M}$ promethazine and $0.6 \mathrm{~cm}^{3}$ of $12 \mathrm{M}$ hydrochloric acid. Quantitative determination of bromated content in the bread samples was carried out following the spectrophotometric method described by El Harti el al. (2011). Absorbance of the sample solution obtained was measured using a spectrophotometer at $515 \mathrm{~nm}$. The concentration of bromate was calculated from the linear regression curve obtained from the working standards. The analysis was done in triplicate and the mean obtained.

Data analysis: Data obtained were analyzed using Microsoft Excel and results were expressed as mean \pm standard deviation.

\section{RESULTS AND DISCUSSION}

Results of this study revealed that all the bread samples analyzed contained potassium bromate (Table 1 and 2).
Result shown in table 1 is the concentration of bromate in bread samples obtained from different locations within Port Harcourt South, Rumueme, Mile 3 and its environment. The highest concentration of bromate was obtained in samples A7 $(0.058 \pm 0.020 \mathrm{mg} / \mathrm{Kg})$, A2 $=\mathrm{A} 10(0.057 \pm 0.020 \mathrm{mg} / \mathrm{Kg})$ and A4 $(0.056 \pm 0.023$ $\mathrm{mg} / \mathrm{Kg}$ ) while the least concentration where for samples A9, A11 and A5 with the following concentrations $0.025 \pm 0.003 \mathrm{mg} / \mathrm{Kg}, 0.027 \pm 0.001$ $\mathrm{mg} / \mathrm{Kg}$ and $0.039 \pm 0.003 \mathrm{mg} / \mathrm{Kg}$ respectively. The result above from the UV spectrophotometric method showed that the range was 0.025 to $0.058 \mathrm{mg} / \mathrm{Kg}$ while the mean value was $0.048 \pm 0.010 \mathrm{mg} / \mathrm{Kg}$. The result clearly indicated that all the bread samples analyzed had concentrations of bromate at levels above the permissible standard set by NAFDAC for bread in Nigeria. This further showed that bread manufacturers in the study area of Port Harcourt south are still using bromate at higher concentration as required by the relevant agency (NAFDAC).

Table 2 showed the result from Port Harcourt North which comprises of Rumuokoro and its environs. The highest concentrations were for samples B4, B1 and $\mathrm{B} 7$ with the values of $0.059 \pm 0.021,0.058 \pm 0.021$ and $0.058 \pm 0.002 \mathrm{mg} / \mathrm{Kg}$ respectively. The lowest values were for samples B3 $(0.011 \pm 0.001 \mathrm{mg} / \mathrm{Kg})$, B10 $(0.020 \pm 0.001 \mathrm{mg} / \mathrm{Kg})$ and B15 $(0.034 \pm 0.001 \mathrm{mg} / \mathrm{Kg})$. The entire samples were higher in concentration than NAFDAC limit except sample B3 and B10 that is same as the limit. The range is 0.011 to $0.059 \mathrm{mg} / \mathrm{Kg}$ and mean of $0.041 \pm 0.008 \mathrm{mg} / \mathrm{Kg}$. The maximum limit of potassium bromate allowed in bread around Nigeria by the NAFDAC is $0.02 \mathrm{mg} / \mathrm{Kg}$ (Ekop et al., (2007).

Table 1: Concentration of Bromate in Bread from Port Harcourt South.

\begin{tabular}{ll} 
& \multicolumn{1}{c}{ South. } \\
\hline Bread Samples & Concentration of Bromate $(\mathbf{m g} / \mathbf{k g})$ \\
\hline A1 & $0.054 \pm 0.003$ \\
A2 & $0.057 \pm 0.020$ \\
A3 & $0.056 \pm 0.002$ \\
A4 & $0.056 \pm 0.020$ \\
A5 & $0.039 \pm 0.003$ \\
A6 & $0.041 \pm 0.002$ \\
A7 & $0.058 \pm 0.020$ \\
A8 & $0.056 \pm 0.023$ \\
A9 & $0.025 \pm 0.003$ \\
A10 & $0.057 \pm 0.002$ \\
A11 & $0.027 \pm 0.001$ \\
A12 & $0.054 \pm 0.020$ \\
A13 & $0.041 \pm 0.021$ \\
A14 & $0.048 \pm 0.002$ \\
A15 & $0.045 \pm 0.003$ \\
Range & $0.025-0.058$ \\
Mean & $0.048 \pm 0.010$ \\
NAFDAC Standard & 0.020 \\
\hline ND Non Detected; Mean \pm Standard Deviation (Std); Analysis \\
was done in triplicate
\end{tabular}


Table 2 Concentration of Bromate in Bread from Port Harcourt North

\begin{tabular}{|c|c|}
\hline $\begin{array}{l}\text { Bread Samples } \\
(\mathrm{mg} / \mathrm{lg}) \mathrm{Bl}\end{array}$ & $\begin{array}{l}\text { Concentration of } \\
\text { Bromate } 0.058=0.021\end{array}$ \\
\hline B2 & $0.039 \pm 0.010$ \\
\hline B3 & $0.011 \pm 0.001$ \\
\hline B4 & $0.059 \pm 0.021$ \\
\hline B5 & $0.050 \pm 0.020$ \\
\hline B6 & $0.039 \pm 0.001$ \\
\hline B 7 & $0.058 \pm 0.002$ \\
\hline B8 & $0.041=0.010$ \\
\hline B9 & $0.040 \pm 0.002$ \\
\hline B 10 & $0.020 \pm 0.001$ \\
\hline B11 & $0.041=0.010$ \\
\hline $\mathrm{B} 12$ & $0.036 \pm 0.002$ \\
\hline B 13 & $0.054 \pm 0.021$ \\
\hline B 14 & $0.043 \pm 0.002$ \\
\hline $\bar{B} 15$ & $0.034 \pm 0.001$ \\
\hline Range & $0.011-0.059$ \\
\hline Mean & $0.041 \pm 0.008$ \\
\hline NAFDAC Standard & 0.020 \\
\hline
\end{tabular}

$N D=$ Non Detected $;$ Mean \pm Standard Deviation (Std); Analysis was done in triplicate

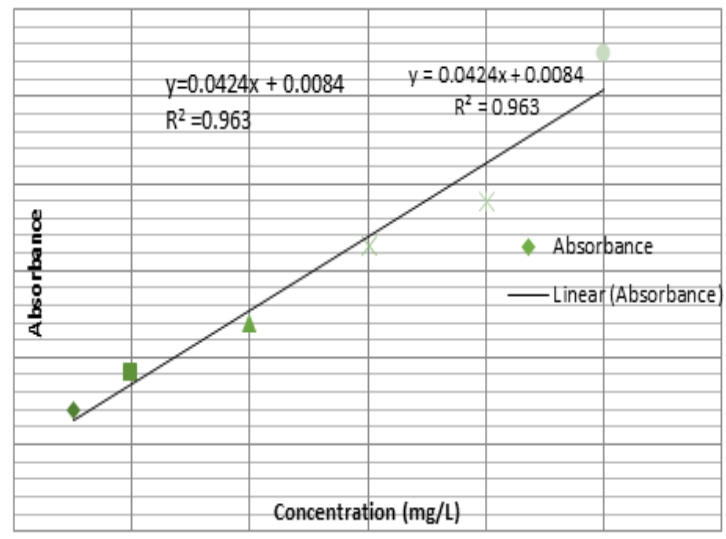

Fig 1: Calibration curve for bromate

All the samples analyzed in this study had potassium bromate in excess of the allowed concentration. Similar Studies by Emeje et al., (2010) carried out in the eastern part of the country also revealed findings that are higher than this work. This study shows result that is far below works by Magomya et al., (2013) who reported potassium bromate level at 2.46 to 13.60 $\mathrm{mg} / \mathrm{kg}$ for bread samples around Zaria and its environment. This substance is also a mutagen and has shown the potential to cause cancer in laboratory animal (Atkins, 1993). Sai et al. (1991), reported that toxicological studies have convincingly shown that potassium bromate affects the nutritional quality of bread by degrading the main vitamins available. High temperature and heat also affects the bread quality and the bromate content of bread. The carcinogenic effect of bromate in laboratory animals has been studied and reported by several scholars (Kurokawa et al., 1990,
Ekop et al., 2007). The levels of potassium bromate in the bread samples were above the limits by NAFDAC. It indicated that bread sold within Port Harcourt is not within safe limits of potassium bromate content. It indicated that potassium bromate is still in use as oxidizing agents for bread which helps to improve its quality but with harmful health effect.

Conclusion: The study reveals that all but few of the analyzed bread brands were above the safe limits of bromate in bread as specified by the US Food and Drug Administration from where NAFDAC also derives her specifications. Therefore, there is the need for authorities to checkmate the bakeries and producers as to ascertain compliance to standard and safety of humans from the side effect that may result from consuming such breads.

\section{REFERENCES}

Abdulla, NS; Hassan, MA (2009). Spectrophotometric determination of bromate in bread by the oxidation of dyes. J. of Kirkuk Uni. -Sci. St., 4(1), 31-39.

Abu-Obaid, A; AbuHasan, S; Shraydeh, B (2016). Determination and degradation of potassium bromate content in dough and bread samples due to the presence of metals. Am. J. of Analyt. Chem. 7:487-493

Akunyili, ND (2005). Eradication of potassium bromated from Nigerian bakery industry. NAFDAC. 5:1-6

Alli, LA; Nwegbu, MM; Bassey, II; Nwachukwu, KC; Ogedengbe, JO; Olufunke, O; Jamda, MA; Ganiyu, AA; Sani, I; Onifade, EA (2013). Determination of potassium bromate content in selected bread samples in Gwagwalada, AbujaNigeria. Int. J. Health Nutr. 4(1), 15-20.

Atkins, DP (1993). Potassium bromate in bread. Index to MAFF UK Food surveillance Information sheets.

Ekop, AS; Obot, BI; Ikpatt, EN (2007). Antinutritional factors and potassium bromated content in bread and flour samples in Uyo Metropolis, Nigeria. E-J. Chem., 5(4), 736-741.

El Ati-Hellal, M; Doggui, R; Krifa, Y (2011). Potassium bromated as food additive: a case study of Tunisian breads. Environ. Sci. Pollut Res. Int., 25:2702-2706 
El-harti, J; Rahali, Y; Benmoussa, A; Ansar, M; Benziane, H; Lamsaouri, J; Idrissi, BOM.; Draoui, M; Zahidi, A; Taoufik, J (2011). A simple and rapid method for Spectrophotometric determination of bromate in bread. J. Mater. Environ. Sci.,

Emeje, MO; Ofoefule, SI; Nnaji, AC; Ofoefule, AU; Brown, SA (2010). Assessment of bread safety in Nigeria: Quantitative determination of potassium bromate and lead J. Food Sci., 4(6) pp. $394-397$.

Emeje, MO; Ofoefule, AU; Brown, SA (2009). Assessment of bread safety in Nigeria: Quantitative determination of potassium bromate and lead. Afr. J. Food sci., 4:394-397

FAO/WHO JECFA (1992) Joint Expert Committee on Food Additives: Evaluation of Certain Food Additives and Contaminants. FAO/WHO JECFA, Geneva, 25-33.

Kurokawa, YA; Maekawa, M; Takahashi, YH; (1990). Toxicity and Carcinogenicity of Potassium Bromate: A New Renal Carcinogen. Environ. Health Per. 87: 309-335
Magomya, AM; Yebpella, GG; Amos, HS; Udiba, UU; Latayo, MS (2013). Potassium Bromate and Heavy Metal Content of Selected Bread Samples Produced in Zaria, Nigeria. Int. J. Sci. Technol., 2(2), $232-237$.

Maziya-Dixon, B; Akinyele, IO; Oguntona, EB; Nokoe, S; Sanusi, RA; Harris, E (2004). Nigeria Food Consumption and Nutritional Survey 20012003. International Institute of Tropical Agriculture (IITA), Ibadan, 67.

Sai, KA; Takagi, TU; (1991). Relation of 8-hydrogen guanosine formation in rat kidney to lipid peroxidation, glutathione level and relative organ weight after a single dose administration of potassium bromate. Jpn. J. Cancer Res. 82(2), 165-169.

Shuaibu, L; Ibrahim, AY; (2012). Spectrophotometric determination of bromated using promethazine. Int. J. Cur. Res., 5(8), 2236-2238 